\title{
PEMBELAJARAN BERBASIS SOSIAL DAN BUDAYA
}

\author{
Yogia Prihartini \\ Wahyudi Buska \\ Universitas Islam Negeri Sulthan Thaha Saifuddin Jambi \\ yogia_prihartini@uinjambi.ac.id
}

\begin{abstract}
Pembelajaran merupakan suatu proses pembudayaan, dalam arti pembelajaran menjadi wahana untuk terjadinya penyampaian budaya ilmiah dan budaya kehidupan bangsa kepada siswa sebagai generasi penerus, terjadinya adopsi budaya ilmiah dan budaya kehidupan komunitas oleh siswa, serta pengembangan budaya dalam suatu komunitas. Namun, pembelajaran sendiri memiliki budaya - tradisi, asumsi, kaidah ilmiah, dll. yang menjadikan pembelajaran sebagai suatu sistem budaya tersendiri. Dari masa ke masa budaya pembelajaran mengalami perubahan, seiring dengan perkembangan ilmu pengetahuan, kemajuan teknologi, dan beragam kebutuhan masyarakat. Dan masyarakat adalah kumpulan individu yang mengatur diri mereka menjadi kelompok tertentu. Untuk menjadi sebuah komunitas, kelompok tertentu harus memiliki kesamaan yang memungkinkan mereka untuk merasakan satu sama lain berbeda dari "kesamaan" mereka sendiri dan lainnya yang pada akhirnya membentuk budaya. Budaya adalah semacam perekat sosial (social cement) yang terdiri dari kebiasaan khas seperti, prinsip, cita-cita, sikap, kepercayaan dan cara berpikir. Jadi jelas perbedaan antara masyarakat dan budaya. Tanpa budaya tidak ada masyarakat, tidak ada komunitas tidak ada budaya

Keywords: Pembelajaran, Sosial , Budaya
\end{abstract}

\section{PENDAHULUAN}

Karakter suatu kebudayaan sangat berpengaruh dalam penyusunan dasar organisasi, tujuan, konten dan evaluasi kurikulum. Meskipun Maurice Jhonnson membatasi konsepnya tentang kurikulum hanya berupa seri terstruktur dari hasil belajar yang diinginkan" namun lebih lanjut dikatakannya "Sumber kurikulum-satu satunya yang mungkin- adalah keseluruhan kebudayaan yang ada" Pentingnya kebudayaan didalam mempelajari kurikulum harus dilanjutkan dengan konsistensi dalam penyusunan kurikulum tersebut. Pertanyaan yang paling sering dikemukakan tentang kurikulum adalah "apakah kurikulum itu dirancang terutama untuk mentransfer kebudayaan kepada generasi muda ataukah untuk mendorong perkembangan individu mereka?" Jadi sangat jelas ada hubungan kurikulum dengan kebudayaan sehingga dapat dikatakan bahwa " kajian tentang kurikulum pada dasarnya adalah kajian tentang masyarakat dan kebudayaan”. 


\section{PEMBAHASAN}

Dalam rangka otonomi pendidikan, setiap sekolah memiliki kewenangan yang penuh dalam mengelola penyelenggaraan program pendidikan. Manajemen berbasis sekolah menuntut keberdayaan sekolah sebagai perancang, pelaksana, sekaligus evaluator dan pengelola proses pendidikan yang berlangsung. Dengan demikian, walaupun rambu-rambu nasional sudah diberikan, sekolah tetap diharapkan mempersiapkan berbagai perangkat yang diperlukan dalam pelaksanaan proses pendidikan, terutama dalam pembelajaran. Hal ini berarti, tidak ada lagi kurikulum nasional - sekolah harus menentukan sendiri kurikulumnya. Tidak ada lagi buku paket, sekolah harus menentukan sendiri bahan ajar yang akan digunakan dalam pembelajaran. Tidak ada lagi tes atau ujian yang tersentralisasi, sehingga sekolah harus mempersiapkan sendiri tes dan ujian untuk mengukur kinerja keberhasilan siswa. Di satu sisi, sistem otonomi pendidikan ini memberikan keleluasaan yang seluas-luasnya kepada sekolah untuk berkreasi dan menempuh beragam upaya yang inovatif untuk mencapai kualitas yang optimal. Namun, di sisi lain, banyak sekolah yang masih merasa gamang untuk beralih tradisi.

Pembelajaran berbasis budaya (PBB) dipersepsikan sebagai salah satu alternatif yang dapat ditempuh oleh sekolah dengan mendekatkan diri dengan komunitas budaya di mana sekolah itu berada. PBB merupakan strategi penciptaan lingkungan belajar dan perancangan pengalaman belajar yang mengintegrasikan seni dan budaya sebagai bagian dari proses pembelajaran. PBB dilandaskan pada pengakuan terhadap seni dan budaya sebagai bagian yang fundamental bagi pendidikan, ekspresi dan komunikasi suatu gagasan, serta perkembangan pengetahuan. PBB menjadikan sekolah sebagai unit pendidikan yang kaya, karena memiliki sumber belajar yang luas - yaitu segala sesuatu yang berada di lingkungan komunitas budayanya, mulai dari sistem sosial, tradisi, kepercayaan, seni dan kesenian, flora dan fauna, serta keseluruhan budaya yang dimiliki oleh komunitas tersebut (Pannen \& Jamaludin, 2003). PBB dipercaya sebagai suatu strategi pembelajaran kreatif yang dapat menjadikan proses pembelajaran sebagai proses yang menyenangkan, menantang, dan menarik sekaligus memberikan konteks nyata bagi pengetahuan dan keterampilan yang diperoleh siswa dari suatu proses pembelajaran; bukan sebagai proses pembelajaran yang menuntut kerja keras, menyeramkan, dan melelahkan.

Banyak penelitian tentang pembelajaran yang menyatakan bahwa pembelajaran yang selama ini berjalan belum menghasilkan lulusan yang memahami peran dan kemanfaatan bidang-bidang ilmu yang telah mereka pelajari dalam kehidupan mereka dalam suatu komunitas budaya. Siswa kebanyakan menghafal beragam teori, prinsip, prosedur keilmuan di sekolah tanpa memiliki pemahaman yang mendalam tentang hubungan bidang-bidang ilmu tersebut dengan keseharian mereka dalam suatu komunitas budaya. Selama ini, pengenalan beragam bidang ilmu dalam proses pembelajaran yang seolah-olah "decontextualized", menjadikan pengalaman budaya (cultural experience and knowledge) yang sudah dimiliki siswa menjadi asing dalam proses pembelajaran. Sebaliknya, beragam ilmu yang diperoleh siswa di sekolah juga 
menjadi asing dalam komunitas budayanya. Kondisi ini banyak diduga terjadi karena adanya kekurangan sumber belajar, yang menyebabkan miskinnya atau minimalnya pengalaman belajar yang diperoleh siswa. Kondisi tersebut semakin menjadi parah dengan adanya budaya pembelajaran di sekolah yang berfokus pada penyelesaian kurikulum bidang ilmu (penyajian setumpuk informasi kepada siswa). Kesemuanya berakibat pada proses pembelajaran yang sangat kering dan tidak menyenangkan, serta hasil pembelajaran yang terbatas pada ruang kelas (Pannen, 2002).

Kalangan ahli pembelajaran menyerukan bahwa pembelajaran haruslah menjadi suatu proses yang menyenangkan, pembelajaran bidang ilmu haruslah "contextualized" untuk mencapai kebermaknaan dalam belajar, dan prior cultural experience and knowledge merupakan faktor penting sebagai suatu titik pijak awal dari proses pembelajaran. Sekolah dapat memanfaatkan beragam sumber belajar yang ada di sekelilingnya - yaitu dalam komunitas budaya di mana sekolah berada. Berdasarkan titik pijak itulah, informasi keilmuan harus disajikan dan dijelaskan relevansinya dengan prior cultural experience and knowledge yang dimiliki masingmasing siswa.

Pemanfaatan seni dan budaya dalam pembelajaran merupakan suatu bentuk perwujudan pembelajaran yang kreatif, kontekstual untuk mencapai hasil belajar yang bermakna. Diharapkan, pemanfaatan seni dan budaya dalam pembelajaran dapat mengubah potret pembelajaran yang selama ini berlangsung menjadi suatu pembelajaran yang berbeda - yaitu yang menyenangkan, bermakna, kreatif, serta yang menjadi pengalaman belajar yang sangat konstruktif bagi siswa. Goldberg (2001) menyatakan bahwa pembelajaran yang memanfaatkan seni dan budaya memungkinkan siswa dan tenaga pengajar menyadari bahwa seni dan budaya merupakan ekspresi ide dan gagasan yang aestetik dalam suatu konteks komunitas budaya. Hal ini mendukung tercapainya pemahaman siswa yang lebih kontekstual dan bermakna terhadap bidang ilmu yang dipelajari.

Berdasarkan pada potensi yang dimiliki oleh PBB, dan bahwa PBB diharapkan dapat diterapkan di sekolah-sekolah, maka PBB menjadi perlu untuk diperkenalkan dalam program pendidikan guru. Hal ini terutama karena guru-lah nantinya yang berperan menerapkan PBB dalam melaksanakan keseharian tugasnya di sekolah. Pemahaman calon guru dalam program pendidikan guru terhadap PBB menjadi penting agar nanti guru dapat menerapkan PBB sebagai salah alternatif pembelajaran kreatif untuk mencapai kualitas hasil belajar yang kontekstual dan optimal.

\section{KOMPLEKSITAS DALAM "KONSEP KEBUDAYAAN"}

Konsep kebudayaan sangat komplek seperti halnya konsep demokrasi, moral dan cinta yang mempunyai beragam makna. Walaupun begitu secara umum kebudayaan dapat didefinisikan sebagai tata cara hidup yang diterima dan diakui pada suatu masyarakat, yang mencakup berbagai aspek - aspek kehidupan yang mudah terlihat seperti barang-barang produksi, organisasi politik dan organisasi sosial, 
mata pencaharian, bentuk-bentuk pakaian, makanan, permainan, musik, tradisi pemeliharaan anak, upacara keagamaan dan acara kenegaraan lainnya.

Namun faktor-faktor yang kelihatan seperti di atas, hanyalah merupakan puncak kecil dari sebuah gunung es kebudayaan. Bahagian yang sangat menentukan dari aspek -aspek kebudayaan yang tidak kelihatan tersebut terdiri dari jalinan ideide, prinsip, kepercayaan, nilai, asumsi, dan cara berfikir yang dianut oleh masyarakat tersebut. Aspek kebudayaan yang tersembunyi inilah yang disebut Psychology of society (Psikologi masyarakat). Aspek-aspek yang tidak disadari ini sangat mempunyai bias pengaruh (Unconscious Culturally Induced Bias) yang dominan terhadap tingkah laku dan perangai suatu masyarakat serta pandangan hidup mereka. Pengaruh bias ini sebenarnya bukan baru dikenal, dan akhir-akhir ini makin terbukti mempunyai pengaruh yang dominan terhadap tingkah laku individu.

Kebudayaan bukan hanya sekedar merupakan kumpulan institusi adat dan kepercayaan. Dalam makna yang lebih nyata ia terdiri dari bagian bagian penting dari lingkungan individu yang membatasi perilakunya ( Melawan grafitasi atau mengurangi sayap untuk terbang). Sementara perbedaan-perbedaan terhadap kepercayaan dan adanya pertentangan-pertentangan cenderung menghasilkan multi sub kelompok di dalam suatu masyarakat budaya yang dominan berfungsi untuk memelihara tatanan sosial dengan membuka kemungkinan bagi pengembangan perilaku individu.

Dapat dikatakan kebudayaan mempunyai kekuatan kontrol yang tidak kelihatan dan jelas lebih dari sekadar merupakan kumpulan lembaga, adat, dan kepercayaan. Di dalam arti yang nyata, budaya merupakan bagian lingkungan individual yang mempengaruhi dan membatasi perilaku masyarakat. Budaya yang dominan berfungsi untuk memelihara tatanan sosial dengan memperluas kemungkinan bagi perkembangan perilaku individual. Oleh karena itu rancangan kurikulum yang paling baik adalah yang paling mengerti kekomplekan pemikiranpemikiran dalam suatu kebudayaan.

\section{PERAN BUDAYA}

Budaya, menurut Vygotsky, "... influences the development of cognitive forms during the transformation of knowledge by providing regulative information that falls within the zone of proximal development". Dalam PBB, budaya menjadi sebuah metode bagi siswa untuk mentransformasikan hasil observasi mereka ke dalam bentuk-bentuk dan prinsip-prinsip yang kreatif tentang suatu pelajaran. Dengan demikian, melalui PBB, siswa bukan sekedar meniru dan atau menerima saja informasi yang disampaikan, tetapi siswa menciptakan makna, pemahaman, dan arti dari informasi yang diperolehnya. Pengetahuan, bukan sekedar rangkuman naratif dari pengetahuan yang dimiliki orang lain, tetapi suatu koleksi (repertoire) yang dimiliki seseorang tentang pemikiran, perilaku, keterkaitan, prediksi dan perasaan, hasil transformasi dari beragam informasi yang diterimanya. 
Dengan demikian, proses pembelajaran berbasis budaya bukan sekedar mentransfer - menyampaikan seni dan budaya atau perwujudan seni dan budaya kepada siswa, tetapi menggunakan seni dan budaya untuk menjadikan siswa mampu menciptakan makna, menembus batas imaginasi dan kreativitas, untuk mencapai pemahaman terpadu tentang suatu pelajaran dalam konteks komunitas budaya. Dalam pembelajaran berbasis budaya, seni dan budaya dapat berperan dalam belajar tentang seni dan budaya, belajar dengan seni dan budaya, dan belajar melalui seni dan budaya (Goldberg, 2000).

Belajar tentang seni dan budaya menempatkan seni dan budaya sebagai bidang ilmu. Proses belajar tentang seni dan budaya, sudah cukup dikenal selama ini, misalnya mata pelajaran kesenian dan kerajinan tangan, seni dan sastra, seni suara, melukis/menggambar, seni musik, seni drama tari, dan lain-lain. Seni dan budaya dipelajari dalam satu mata pelajaran khusus, tentang seni dan budaya dan untuk seni dan budaya. Belajar dengan seni dan budaya terjadi pada saat seni dan budaya diperkenalkan kepada siswa sebagai cara atau metode untuk mempelajari MIPA. Belajar dengan seni dan budaya meliputi pemanfaatan beragam bentuk perwujudan seni dan budaya. Dalam belajar dengan seni dan budaya, maka seni dan budaya dan perwujudannya menjadi media pembelajaran dalam proses belajar, menjadi konteks dari contoh-contoh tentang konsep atau prinsip dalam suatu mata pelajaran, menjadi konteks penerapan prinsip atau prosedur dalam suatu mata pelajaran. Sementara itu, belajar melalui seni dan budaya merupakan metode yang memberikan kesempatan kepada siswa untuk menunjukkan pencapaian pemahaman atau makna yang diciptakannya dalam suatu mata pelajaran melalui ragam perwujudan seni dan budaya. Belajar melalui seni dan budaya menjadi salah satu bentuk multiple representation of learning assessment, atau bentuk penilaian pemahaman dalam beragam bentuk.

Indonesia memiliki seni dan budaya yang sangat kaya dan beragam dari berbagai etnis suku bangsa yang tinggal di 17.000 pulau dari Sabang sampai Merauke. Secara umum, seni dan budaya Indonesia dibagi menjadi beberapa wilayah atau simpul seni dan budaya yang didasarkan pada seni dan budaya wilayah Aceh, Batak, Minang, Betawi, Sunda, Jawa Tengah, Jawa Timur, Bali, Lombok, Dayak, Sulawesi, dan Papua. Setiap simpul seni dan budaya mewakili beragam seni tradisi dan budaya dari lingkungan wilayahnya.

Namun demikian, di tengah kekayaannya, salah satu isu yang menjadi tantangan dunia pendidikan di Indonesia pada saat ini adalah semakin menurunnya apresiasi dan upaya pelestarian seni dan budaya dari masyarakat, karena belum meratanya perhatian dan dukungan masyarakat terhadap seni dan budaya. Secara umum, dapat dikatakan bahwa sesungguhnya seni dan budaya belum imengerti dan belum menjadi perhatian banyak kalangan di Indonesia, kecuali kalangan seni dan budaya itu sendiri. Seni dan budaya masih dipersepsikan banyak orang Indonesia sebagai sesuatu yang "ekslusif" - hanya milik segelintir orang. Ketika seni dan budaya menjadi ekslusif, seni dan budaya menjadi asing dalam komunitas budayanya sendiri, sebagaimana 
disinyalir dalam tulisan "Masyarakat kita sudah asing terhadap kebudayaannya sendiri" (Festival Kebudayaan Melayu Serumpun) (Kompas, 19 Des.2002).

Kebanyakan kalangan selalu melihat seni dan budaya sebagai sesuatu yang berada di belakang, di bawah, bukan prioritas, dan tidak memperoleh perhatian yang cukup, dibandingkan dengan bidang-bidang ilmu lain. Begitu juga dinyatakan oleh ahli budaya Indonesia bahwa "Negara tempatkan budaya minoritas sebagai subordinat" dalam Seminar: Pembangunan Berwawasan Budaya: Agenda untuk Solusi (Kompas, 19 Des.2002). Yang lebih parah lagi, kata seni dan budaya seringkali berkonotasi negatif, karena dipersepsikan sebagai sesuatu yang tradisional jika dibandingkan dengan kata teknologi yang sealalu dikaitkan dengan modernisasi. Dengan demikian, seni dan budaya diperlakukan sebagai suatu entitas yang berada di luar wilayah pendidikan umum yang formal (kecuali pendidikan seni yang khusus untuk seni), dan tidak pernah dipersepsikan sebagai suatu konteks (komunitas budaya) yang sangat berharga dalam perkembangan pemahaman siswa terhadap suatu bidang ilmu.

\section{STRUKTUR BUDAYA}

Linton mengklasifikasikan elemen budaya menjadi 3 katagori utama yaitu yang bersifat " universal, khusus, dan alternatif"

\section{Universal}

Struktur kebudayaan universal adalah semua nilai-nilai , kepercayaan dan adat istiadat yang dianut oleh semua anggota masyarakat dewasa. Misalnya beberapa macam kebiasaan pada daerah tertentu, tentang penggunaan bahasa, jenis makanan, kepercayaan dan sistim ekonomi yang dipakai. Tentu saja beberapa variasi akan timbul dan pada hal-hal tertentu mungkin dapat menimbulkan sanksi bagi hal-hal yang dianggap taboo. Kadang-kadang sanksi ini bisa menjadi brutal atas penyimpangan yang dilakukan pada elemen universal.

\section{Spesialistis / Khusus}

Mencakup aspek -aspek kebudayaan yang ditemukan hanya pada subkelompok dari sebuah masyarakat. Sub kelompok masyarakat ini berkaitan dengan lingkungan kerja anggota masyarakat , nilai-nilai yang dianutnya, adat istiadat, agama atau kepercayaan tertentu yang berbeda dengan tingkah laku , nilai , makanan, agama dari orang -orang dari kelompok etnik yang berbeda.

Klasifikasi aspek kebudayaan khusus ini dapat juga berkaitan dengan tingkat kelas sosial (tinggi, menengah, rendah) atau jenis kelamin (pria dan wanita) atau umur (anak, pemuda dewasa dan lainnya).Tentu saja bisa terjadi cara berpikir , tingkah laku , nilai-nilai tertentu overlap dengan cara berpikir, tingkah laku atau nilai dari subgroup lainnya. 
Alternatif:

Adalah aspek kepercayaan dan tingkah laku masyarakat tertentu yang berlainan atau bahkan bertentangan dengan norma-norma umum yang berlaku dimasyarakat yaitu yang universal dan khusus. Hal ini timbul dalam usaha mencoba mengisi kebutuhan, memecahkan masalah atau penyesuaian dari kenyataan yang ada. Jadi elemen alternatif ini adalah bahwa ia berbeda dari universal dan khusus, karena elemen alternatif ini menawarkan pada anggotanya suatu pilihan baru (New Morality).

Elemen kebudayaan ini mempunyai persamaan dengan dengan elemen khusus karena elemen-elemen itu berbeda dengan universal. Kebudayaan alternatif ini juga berbeda dengan elemen khusus karena elemen-elemen itu tidak ada yang sama dengan yang dimiliki subgroup. Misalnya perobahan tradisi snak sesudah menonton dari hamburger ke pizza. Atau juga bisa ditemukan bahasa-bahasa khusus diantara anak muda.

Pada dasarnya kurikulum disusun dan dikembangkan untuk mengintervensi kehidupan anak sedemikian rupa agar mereka menjadi "seseorang" yang tanpa kurikulum tidak menjadi orang yang diinginkan. Untuk maksud tersebut terasa penting bagi perancang kurikulum untuk memahami benar kebudayaan universal dan khusus dan membandingkannya dengan segala bentuk kebudayaan alternatif.

Yang biasa ditemui saat ini adalah kurikulum disusun serta diimplementasikan untuk mentrasfer nilai-nilai kebudayaan yang ada seefisien mungkin kepada anak didik tanpa mengevaluasi apakah nilai tersebut relevan dengan masa kini dan masa depan yang berubah cepat. Praktek seperti ini pada hakekatnya tidak berbeda dengan indoktrinasi. Sedang untuk mendidik diperlukan kurikulum yang membuka lebar -lebar bagi kesempatan untuk mengkaji, serta mengevaluasi aspek-aspek kebudayaan yang universal dan yang khusus dalam kaitannya dengan aspek-aspek kebudayaan alternatif yang diinginkan bagi pertumbuhan anak didik itu sendiri.

\section{PEMBELAJARAN BERBASIS BUDAYA}

Pengalaman belajar (learning experience) dan proses penciptaan (creation process) biasanya berawal dari konteks yang sudah dikenal oleh seseorang, yaitu komunitas budaya di mana orang tersebut berada. Gaya hidup, sistem nilai, tradisi, lingkungan di sekitarnya (flora, fauna, musim, dll.), serta benda-benda seni dan budaya di sekitarnya mempunyai peran penting dalam mewarnai dan mempengaruhi perkembangan diri seseorang, proses belajar, serta proses penciptaan yang dilakukannya kemudian. Kedekatan seseorang dengan komunitas budayanya seakan terputus ketika ia harus menjalankan proses belajar di bangku pendidikan formal. Melalui proses sekolah, seseorang dituntut untuk menguasai berbagai bidang ilmu universal yang disajikan kepadanya melalui proses pembelajaran. Banyak penelitian tentang pembelajaran menyatakan bahwa pembelajaran yang selama ini berjalan belum menghasilkan lulusan yang memahami peran dan kemanfaatan bidang-bidang ilmu yang telah mereka pelajari dalam kehidupan mereka dalam suatu komunitas 
budaya. Siswa menghafal beragam teori, prinsip, prosedur keilmuan di sekolah tanpa memiliki pemahaman yang mendalam tentang hubungan bidang-bidang ilmu tersebut dengan keseharian mereka dalam suatu komunitas budaya. Artinya, pembelajaran lebih menekankan sifat universal daripada kontekstual.

Semakin banyak interaksi seseorang dengan bidang ilmu yang universal - yang disajikan semata-mata untuk penyelesaian kurikulum dan mencapai kelulusan semakin jauh ia dari komunitas budayanya. Seakan-akan bidang ilmu yang dipelajarinya di sekolah tidak ada hubungannya dengan komunitas budayanya, begitu pula sebaliknya. Sementara itu, pengalaman budaya yang sudah dimiliki siswa pun tidak memiliki tempat dalam proses pembelajaran. Kesemuanya berakibat tidak hanya pada proses pembelajaran yang tidak menyenangkan serta hasil pembelajaran yang terbatas pada ruang kelas, tetapi juga menyebabkan seni dan budaya yang sudah tumbuh dan berkembang dalam komunitas budaya menjadi semakin tidak dikenal, tidak diapresiasi, dan bahkan ditinggalkan.

Pemanfaatan seni dan budaya dalam pembelajaran merupakan suatu bentuk perwujudan pembelajaran yang kreatif, kontekstual, yang didasarkan pada prior cultural experience and knowledge yang dimiliki masing-masing siswa untuk mencapai hasil belajar yang bermakna. Diharapkan, pemanfaatan seni dan budaya dalam pembelajaran dapat mengubah suasana pembelajaran menjadi suatu pembelajaran yang menyenangkan, bermakna, kreatif, kontekstual, serta konstruktif bagi siswa. Pada saat bersamaan, pembelajaran tersebut juga memberikan kesempatan kepada siswa dan guru untuk mengenal dan mengapresiasi seni dan budaya yang dimiliki oleh komunitas budayanya. Murgiyanto (1999) menyatakan bahwa bidang ilmu hanya mementingkan olah tubuh dan olah pikir, tapi kurang diimbangi rasa keindahan atau olah rasa. Sebaliknya, kesenian cenderung meninggalkan kecerdasan, rasa lebih ditonjolkan. Oleh karena itu, pemanfaatan seni dalam pembelajaran akan memberikan alternatif yang lebih banyak lagi untuk berfokus pada olah tubuh, olah pikir, dan olah rasa pada saat bersamaan.

Menurut Goldberg (2001), pembelajaran yang memanfaatkan seni dan budaya memungkinkan siswa dan tenaga pengajar menyadari bahwa seni dan budaya merupakan ekspresi ide dan gagasan yang aestetik dalam suatu konteks komunitas budaya. Hal ini mendukung tercapainya pemahaman siswa yang lebih kontekstual dan bermakna terhadap bidang ilmu yang dipelajari, sekaligus pengenalan dan apresiasi seni dan budaya dalam komunitas budayanya.

Pemanfaatan seni dan budaya dalam pembelajaran, atau disebut dengan Pembelajaran Berbasis Budaya (PBB) merupakan strategi penciptaan lingkungan belajar dan perancangan pengalaman belajar yang mengintegrasikan seni dan budaya sebagai bagian dari proses pembelajaran, dan mengakui seni dan budaya sebagai bagian yang fundamental bagi pendidikan, ekspresi dan komunikasi suatu gagasan, serta perkembangan pengetahuan (Pannen, 2002). PBB merupakan salah satu cara yang dipersepsikan dapat 1) menjadikan pembelajaran bermakna dan kontekstual sangat terkait dengan komunitas budaya di mana suatu bidang ilmu dipelajari dan 
akan diterapkan nantinya, dan dengan komunitas budaya dari mana siswa berasal; serta 2) menjadikan pembelajaran menarik dan menyenangkan.

Dalam PBB, seni dan budaya diintegrasikan sebagai alat bagi proses belajar untuk memotivasi siswa dalam mengaplikasikan pengetahuan, bekerja secara kooperatif, dan mempersepsikan keterkaitan antara berbagai bidang ilmu. Sebagai strategi, PBB mendorong terjadinya proses imaginatif, metaforik, berpikir kreatif, dan juga sadar budaya. Partisipasi dengan dan melalui beragam bentuk perwujudan seni dan budaya memberikan kebebasan bagi siswa untuk belajar dan memperoleh pengertian yang mendalam serta terpadu tentang prinsip-prinsip dalam suatu mata pelajaran, dan hal-hal baru yang bermakna di sekelilingnya. PBB menjadikan proses pembelajaran sebagai arena untuk eksplorasi bagi siswa maupun tenaga pengajar, dalam mencari pemahaman dan mencapai pengertian serta rasional ilmiah dalam bidang ilmu, mewujudkan pengembangan keterampilan sampai tercapai keahlian, mencari strategi untuk mencapai pemahaman dan perkembangan keterampilan tersebut, sambil sekaligus mengenal dan mengapresiasi seni dan budaya dalam komunitasnya.

Dalam PBB, seni dan budaya juga menjadi sebuah metode bagi siswa untuk mentransformasikan hasil observasi mereka ke dalam bentuk-bentuk dan prinsipprinsip yang kreatif tentang alam dan kehidupan. Melalui PBB, siswa bukan sekedar meniru dan atau menerima saja informasi yang disampaikan, tetapi siswa menciptakan makna, pemahaman, dan arti dari informasi yang diperolehnya dalam beragam bentuk perwujudan. Pengetahuan, bukan sekedar rangkuman naratif dari pengetahuan yang dimiliki orang lain, tetapi suatu koleksi yang saling terkait (repertoire) yang dimiliki seseorang tentang pemikiran, perilaku, keterkaitan, prediksi dan perasaan, hasil transformasi dari beragam informasi yang diterimanya. Dengan demikian, proses PBB bukan sekedar mentransfer - menyampaikan seni dan budaya atau perwujudan budaya kepada siswa, tetapi menggunakan seni dan budaya untuk menjadikan siswa mampu menciptakan makna, menembus batas imaginasi dan kreativitas, untuk mencapai pemahaman yang mendalam tentang bidang ilmu yang dipelajarinya.

PBB pada dasarnya memperluas konsep pendidikan di Indonesia dengan mengakomodasikan tiga macam proses belajar melalui integrasi seni dan budaya, yaitu belajar tentang seni dan budaya (dalam pendidikan seni untuk seni dan budaya, belajar dengan seni dan budaya), dan belajar melalui seni dan budaya. Sekali lagi, dalam pendidikan seni untuk seni dan budaya, proses belajar tentang seni dan budaya menempatkan seni dan budaya sebagai bidang ilmu. Seni dan budaya dipelajari dalam satu jurusan atau program studi khusus, tentang seni dan budaya serta untuk seni dan budaya. Sementara itu, belajar dengan seni dan budaya terjadi pada saat seni dan budaya diperkenalkan kepada siswa sebagai cara atau metode untuk mempelajari suatu bidang ilmu tertentu. Belajar dengan seni dan budaya meliputi pemanfaatan beragam bentuk perwujudan budaya dan karya seni untuk belajar. Belajar melalui seni dan budaya merupakan strategi yang memberikan kesempatan kepada siswa untuk menunjukkan pencapaian pemahaman atau makna 
yang diciptakannya dalam suatu bidang ilmu melalui beragam perwujudan budaya dan hasil karya seni (multiple representation of understanding).

Dalam PBB, siswa akan berinteraksi dengan seni dan budaya, melalui beragam proses, termasuk mengapresiasi karya seni dan budaya. Apresiasi karya seni dan budaya mengajak individu untuk berpikir dan bekerja melintasi beragam bidang ilmu, karena sesungguhnya karya seni dan budaya mengintegrasikan beragam cabang bidang ilmu menjadi suatu wujud nyata. Adalah melalui karya seni dan budaya, seseorang belajar untuk memahami perbedaan dan dimensi dunia yang multibudaya, mempersepsikan keterkaitan antara berbagai bidang ilmu, serta memiliki ketajaman dalam penilaian kualitas. Apresiasi karya seni dan budaya, persentuhan dengan karya seni dan budaya, serta keterampilan berkarya seni dan berbudaya mendorong terjadinya proses imaginatif dan kreatif, serta sadar budaya yang merupakan ciri manusia cerdas luaran dari proses pembelajaran yang bermakna.

\section{KEBUDAYAAN DAN NILAI}

Seperti kita ketahui bahwa kebudayaan menentukan pandangan, tata cara hidup dan tingkah laku masyarakat, yang merupakan tata cara hidup yang lebih dapat diterima dan lebih baik dari tata cara hidup lain.. Oleh karena itu, kita dapat melihat kebudayaan sebagai sebuah sesuatu yang penuh muatan nilai. Ia membuat masyarakat dapat menentukan perbuatan yang baik dan yang buruk; yang indah dan yang jelek, "yang boleh dilakukan" dan "yang tidak boleh dilakukan".

Seperti juga konsep kebudayaan maka nilai adalah konsep yang juga rumit. Kesulitan terbesar terletak pada area penafsiran yang akurat terhadap nilai yang dianut oleh individu maupun masyarakat sebagaimana yang dipertanyakan oleh Van Cleve Morris, "bagaimana menentukan nilai -nilai yang dianut oleh seseorang dengan kenyataan nilai-nilai yang dilaksanakannya. Salah satu jawaban yang ditawarkan oleh Charles Morris dengan membedakan antara conceived values (nilai yang dipikir orang, yang mereka percayai) dengan operatif values (nilai-nilai yang tersirat dari perilaku mereka). Umumnya pada masyarakat akan ditemui diskrepensi antara apa yang dinilaikan dengan apa yang dilaksanakan (Action speaks louder than words). Contoh nyata kita lihat sesudah 200 th kemerdekaan Amerika simbol-simbol keadilan yang digalakkan hanya semboyan karena penyiksaan terhadap masyarakat berwarna berjalan terus.

Dalam bagian sebelumnya kita mengamati bahwa budaya terdiri dari bagian lingkungan yang penting, \& karena itu mesti didefenisikan dalam pengertian individu dapat menjalankan kehidupan sehari-hari. Pada bagian ini kita akan meneliti lebih detil beberapa konsep yang dapat membantu kita untuk lebih mengerti kompleksitas dari keseluruhan fenomena budaya. 


\section{KEPRIBADIAN "NORMAL" DAN KEBUDAYAAN}

Karena kebudayaan menentukan tata cara hidup dan perbuatan masyarakat maka dapat dimengerti bahwa kebudayaan juga menentukan perkembangan kepribadian. Oleh karena itu kebudayan bertujuan untuk menciptakan pada setiap anggota masyarakat sebuah tipe kepribadian yang ideal sehingga menghasilkan individu yang secara teoritis merefleksikan konfigurasi nilai, karakteristik, sikap dan perilaku yang secara budaya sempurna.

Sebuah kurikulum biasanya dinilai "baik" ketika dia bisa menghasilkan individu dalam jumlah yang besar yang kepribadiannya memungkinkan mereka untuk masuk dan berfungsi dengan baik dalam masyarakatnya. Sebaliknya ia dinilai jelek ketika ia mengembangkan individu yang kepribadiannya cukup menyimpang dari norma-norma sehingga menimbulkan "masalah" bagi masyarakat.

Meskipun "tipe ideal" tidak pernah ditemukan dalam masyarakat manapun, standarisasi budaya dari kepribadian cukup sering muncul, sehingga kita dengan gampang dapat mengenali kepribadian yang "normal".

Konsep tentang "ideal" dan "normal", sebagaimana dipergunakan disini, hanya mempunyai arti di dalam konteks suatu masyarakat tertentu.

Harus diingat bahwa konsep kepribadian yang "normal" secara antropologis hanyalah merupakan satu cara untuk menjelaskan tentang kepribadian dan memberikan perbandingan yang menarik terhadap teori individualistik tentang sifat manusia dan perkembangan kepribadian yang menggaris bawahi psikologi.

Jd Benedict meletakkan dasar tentang perbandingan 3 budaya primitif, masing masingnya berbeda dari yang lain seperti jang beda dari budaya sendiri; \& study memperlihatkan bagaimana, berbagai budaya menghasilkan kepribadian yang secara dramatis dianggap "normal". Utk membantu kita mengerti kondisi fenomena ini kita akan meneliti secara singkat budaya dari 2 masyarakat sebagamana dijelaskan oleh Benedict; Masy Pueblo di NewMexico \& Dobuan di Pasifik Selatan.

Benedict menjelaskan orang Indian Pueblo di New Mexico sebagai masyarakat yang lambat, anti kekerasan, tidak emosional, moderen ,kooperatif, \& menekankan pada komunitas. Pada masyarakat Pueblo, ambisi personal \& pencapaian individu dianggap rendah. Bahkan dalam permainan /pertandingan, jika seseorang menang secara terus menerus, dia tidak boleh ikut lagi berpartisipasi;orang Pueblo tertarik hanya pada aktifitas yang melibatkan banyak orang dengan kesempatan yang sama.

\section{PERUBAHAN BUDAYA PEMBELAJARAN}

PBB membawa budaya pembelajaran yang berbeda dari pembelajaran yang terjadi selama ini. Brooks \& Brooks (1993) menyatakan bahwa "... making a difference is when students work with adults (i.e., teachers) who continue to view themselves as learners, who ask questions with which they themselves still grapple, who are willing and able to modify both content and practices in the pursuit of meaning, and who treat students and their endeavors as works in progress which are 
uniques, not uniformed finished products". Dalam mengupayakan perubahan tersebut, bukan hanya suasana pembelajaran dan perancangan pembelajaran yang diharapkan dimodifikasi dan dikembangkan, namun juga budaya pembelajarannya.

Pembelajaran sendiri merupakan suatu proses pembudayaan, dalam arti pembelajaran menjadi wahana untuk terjadinya penyampaian budaya ilmiah dan budaya kehidupan bangsa kepada siswa sebagai generasi penerus, terjadinya adopsi budaya ilmiah dan budaya kehidupan komunitas oleh siswa, serta pengembangan budaya dalam suatu komunitas. Namun, pembelajaran sendiri memiliki budaya tradisi, asumsi, kaidah ilmiah, dll. yang menjadikan pembelajaran sebagai suatu sistem budaya tersendiri. Dari masa ke masa budaya pembelajaran mengalami perubahan, seiring dengan perkembangan ilmu pengetahuan, kemajuan teknologi, dan beragam kebutuhan masyarakat.

Seruan perubahan budaya pembelajaran dari budaya yang berfokus pada tenaga pengajar atau materi bidang ilmu (teacher-centered atau content-centered) menuju budaya pembelajaran yang berfokus pada siswa telah dimulai sekitar akhir tahun 1960-an dan atau awal tahun 1970-an. Namun demikian, sampai sekarang pembelajaran tradisional yang berbasis pada tenaga pengajar atau materi bidang ilmu (pemenuhan kurikulum) masih sangat umum dijumpai. Misalnya dalam pembelajaran MIPA, dengan dalih berbagai kendala dan keterbatasan (peralatan, laboratorium, dll.), sangat umum terjadi proses pembelajaran "sastra MIPA" - atau yang disebut oleh Lythcott \& Stewart (2001) sebagai "inherited language science". PBB menyerukan terjadinya perubahan berbagai komponen dalam pembelajaran, yaitu agar tenaga pengajar, siswa, kurikulum, dan proses belajar menghasilkan perbedaan peningkatan kualitas - dalam proses pembelajaran maupun hasil pembelajaran, atau secara umum dalam budaya pembelajaran.

\section{BAHASA}

Penelitian linguistik beberapa dekade ini telah memperlihatkan bahwa bahasa adalah merupakan satu aspek sangat penting dari budaya, bukan karena bahasa bekerja sebagai sebuah alat untuk mengekspresikan ide budaya, melainkan karena ia bekerja dengan cara sangat kuat dan halus sebagai alat untuk mempertajam ide-ide. Poin ini menjadi sangat penting mengingat fakta bahwa ada lebih dari 2000 sistem bahasa di dunia.

Untuk melihat bagaimana bahasa berfungsi baik disimak karya Benjamin Lee Whorf. Yang memulai teorinya dengan mengemukakan bahwa orang tidak akan menyadari kondisi tertentu sampai ada gangguan terhadap keteraturan kondisi tersebut, seperti orang tidak menyadari keberadaan udara sampai dia mengalami ganggaun bernafas.

Orang cenderung untuk melihat budayanya sebagai merepresentasikan cara hidup yang "alamiah" dan "universal", sampai ada interupsi terhadap cara hidup itu, dan sampai mereka menyadari ada budaya lain. Tetapi di dalam kebanyakan budaya, fenomena bahasa tidak disadari oleh pengguna bahasa biasa. Whorf dengan sangat 
jelas membandingkan struktur dasar dari bahasa Inggris dengan beberapa bahasa yang tidak berhubungan satu sama lain.

\section{MEDIA}

Media adalah teknologi yang digunakan untuk memindahkan informasi, yang telah dikenal secara luas sebagai hal penting bagi berfungsinya semua kegiatan masyarakat seperti radio, film, dan televisi. Termasuk juga teknologi seperti telepon, fonograf, foto, sepeda, mobil, dan pesawat.

Diasumsikan secara luas bahwa media adalah bahwa ia adalah alat penyampai informasi pesan yang netral yang terdiri dari medium dan mesage dengan entiti yang terpisah dan berbeda.

Barangkali hal terpenting bagi mahasiswa yang mempelajari kurikulum adalah analisa komparatif McLuhan tentang efek dari media cetak dan media elektronik, karena masyarakat kita berada di tengah suatu revolusi teknologi komunikasi. Menurut McLuhan, media cetak adalah suatu "ditto device", yang mengkonfrmasi penekanan visual dari bahasa tertulis. Menurt McLuhan, logika telah menjadi sangat tergantung pada representasi visual, sehingga kita menyamakan "rasional" dengan "seragam, berkelanjutan, dan beraturan". Akibat lain dari teknologi cetak adalah ia mempopulerkan penggunaan buku yang mudah dan nyaman dibawa. Sebaliknya McLuhan mengatakan bahwa peredaran media elektronik telah menciptakan "massa" - sebuah dunia dengan partisipan yang saling tergantung, sebuah dunia yang disebutnya kampung global. Kondisi ini telah disebabkan terutama oleh televisi.

Sebegai pembanding, Mc Luhan mengatakan bahwa lingkaran media elektronik telah menciptakan "massa" sebuah dunia dengan partisipan yang saling tergantung, sebuah dunia yg disebutnya "kampung global". Kondisi ini disebabkan itu oleh TV, yang "menghendaki partisipasi \& keterlibatan yang dalam dari semua orang”. Keterlibatan ini tidak terbatas hanya secara visual,namun jang melibatkan perasaan \& emosi secara luas.Dia jg mengenali kenyataan bahwa banyak dari pengalaman sadar memiliki "visualitas" yg terbatas. Mc Luhan mengutip upacara pemakaman Kennedy yg disiarkan TV sebagai sebuah peristiwa yang memperlihatkan kekuatan media ini untuk mendapatkan partisipasi total pnduduk seluruh dunia dalam sebuah pengalaman yang sama.

\section{FAKTOR SOSIAL-PSIKOLOGIS YANG MENGAKIBATKAN BIAS KULTURAL}

Penelitian sosial psikologis telah mendapatkan beberapa faktor kultur psikologis yang menimbulkan distorsi impresi manusia mengenai hal-hal yang dihadapinya sehari-hari. Situasi ini diterima sedemikian rupa dan lumrahnya manusia melihat sesuatu tidak akurat, dan melihat keadaan tersebut dari segi pandang motivasi egosentris manusia itu sendiri.

Klineberg meneliti tentang dasar kultural dari persepsi manusia, dan mereview kembali faktor-faktor yang menyumbang kepada ketidakmampuan kita 
untuk melihat lingkungan secara akurat. Dia menunjukkan bahwa persepsi manusia tergantung kepada:

1. Persepsi kita terhadap sesuatu terpengaruh oleh latihan-latihan yang kita peroleh dari pengalaman kita terdahulu. Misalnya ada suku yang menolak makan daging kuda karena pengalaman sebelumnya tidak ada.

2. Manusia dalam melihat sesuatu tergantung pada pengharapannya dan keinginnannya masing-masing. Misalnya mahasiswa yang lapar cenderung mengambar sejenis makanan

3. Manusia melihat sesuatu tergantung atas adanya pengaruh orang lain

Sehubungan dengan "harapan" adalah "keinginan", dan Klineberg menunjukkan bahwa banyak kesalahan di dalam persepsi kita disebabkan oleh fenomena pemenuhan keinginan ini.

Paling kurang ada dua konsep lain yang berhubungan dengan masalah yang kita perbincangkan: persepsi egosentris dan ramalan pemenuhan diri.

Persepsi egosentris adalah kecenderungan untuk melihat situasi dalam kerangka etnis sendiri, pekerjaan, sosio-ekonomi, atau identifikasi nasional - yaitu serangkaian kebutuhan, nilai, kepercayaan, harapan, dan prinsip.

Apa kemungkinan untuk menghindari situasi ini? Osgood (dalam Klineberg, 1964: 96) mengemukakan tiga tingkatan pikiran sosial:

1. Kita secara sadar memaksakan referensi kita terhadap orang lain.

2. Kita mengenali sifat relativistik kerangka referensi orang lain tetapi tidak mengenali kerangka referensi kita.

3. Kita mengenali persamaan sifat relativistik dari semua kerangka referensi, termasuk milik kita.

Implikasi Kurikulum terhadap uraian diatas mengenai hakekat masyarakat dan kebudayaan menurunkan beberapa implikasi. Implikasi ini relevan dengan fungsi sekolah sebagai institusi sosial dan kurikulum sekolah.

\section{NILAI, BIAS KEBUDAYAAN DAN KURIKULUM}

Bagian sebelumnya memperlihatkan bahwa masyarakat melengkapi dirinya dengan menanamkan nilai di dalam berbagai cara psikologisnya , yang menghasilkan bias kebudayaan yang tak disadari. Efek dari bias kebudayaan ini terhadap kurikulum sekolah ditemukan adanya beberapa pesan proses kebudayanan alamiah

Beberapa contoh tentang hubungan antara bias budaya dan praktek kurikulum akan memperlihatkan poin ini:

1. Peranan seks yang dianut di Amerika telah lama adalah anggapan bahwa "tempat perempuan di rumah", dan bahwa pekerjaan perempuan dibatasi pada memasak, urusan rumah tangga, mengurus anak, dan pekerjan-pekerjaan domestik lainnya. Bias kebudayaan yang tak disadari telah diterima secara global dan hanya dengan perobahan sosial keadaan ini akan dievaluasi lagi. 
Yogia Prihartini, Wahyudi Buska; Pembelajaran Berbasis Sosial Dan Budaya

2. Contoh lain dari hadirnya bias kultural secara tidak disadari di dalam kurikulum ada dalam hubungannya dengan peranan kulit hitam dalam masyarakat Amerika. Sebelum gerakan hak asasi pada tahun 1960 an, orang hitam umumnya merupakan sub-kelompok yang "tidak kelihatan" dalam masyarakat.

3. Contoh terakhir dari bias kultural yang tidak disadari di dalam kurikulum, ada hubungannya dengan sentimen nasionalis.

Dengan cara apakah kurikulum sekolah menerapkan kepercayaan bahwa nasionalisme adalah hal yang alamiah dan merupakan sistem pemerintahan dunia yang paling diminati.Mula-mula (dan terutama) dengan cara menanamkan patriotisme. Sulit sekali untuk menentang patriotisme karena melakukan itu berarti "pengkhianat", atau paling kurang subversif. Patriotisme mencakup kesetiaan terhadap kelompok sendiri dan nilai ini sering membawa kebaikan bagi kita. Pengajaran tentang nasionalisme dimulai pada kelas-kelas paling dasar dengan pelajaran tentang bendera, sumpah persekutuan, pahlawan nasional, mitologi nasional masa awal dan sebagainya.

Di kelas dasar yang lebih tinggi kita menemukan bahwa nasionalisme tercakup dalam sejumlah besar kurikulum tentang membaca, sejarah, geografi, dan literatur.Pada kenyataannya sekarang kita lihat bahwa telah terjadi perobahan sikap kebudayaan kearah internasional, terutama sejak terjadinya persaingan AS dan Unisofyet dimana beberapa sekolah di US telah memulai program internasional dan kebudayaan multinasional.

\section{KESIMPULAN}

Pembelajaran berbasis budaya mungkin bukan merupakan suatu terobosan yang sama sekali baru, namun suatu semangat baru yang perlu terus dipelihara dan dikobarkan untuk "making a difference", yaitu membuat perbedaan dalam proses pembelajaran - pembelajaran bidang ilmu sekaligus pembelajaran seni dan budaya. Pembelajaran berbasis budaya merupakan perluasan bentuk pembelajaran yang mampu membuat pembelajaran bidang ilmu menjadi contextualized dalam komunitas budaya siswa. Hal ini juga menjadikan pengalaman budaya yang dimiliki siswa berperan penting dalam pembelajaran, serta pengetahuan keilmuan yang diperoleh siswa dari sekolah menjadi bermakna bagi keseharian siswa dalam komunitas budayanya. Pembelajaran berbasis budaya membuat pembelajaran menjadi kaya dalam arti siswa belajar tentang bidang ilmu sekaligus tentang seni dan budaya dalam komunitasnya. Dalam PBB, baik guru maupun siswa belajar bidang ilmu sekaligus belajar seni dan budaya. Pada akhirnya, pembelajaran berbasis budaya yang sangat mengakomodasikan kebebasan siswa untuk berekspresi menjadikan pembelajaran menyenangkan, relevan, kreatif, dan bermakna, sekaligus meningkatkan kemampuan siswa dan guru untuk mengapresiasi seni dan budaya dalam komunitas budaya mereka. 
Untuk lebih memperoleh gambaran yang lebih jelas tentang PBB, terutama potensinya dalam menjadikan pembelajaran bidang ilmu kontekstual dan menarik serta menyenangkan, dengan hasil belajar yang berkualitas, masih diperlukan serangkaian kajian yang lebih mendalam berkenaan dengan PBB, dari berbagai aspeknya. Hasil yang telah dicapai saat ini hendaknya menjadi pemicu untuk penelitian dan pengembangan PBB lebih lanjut dalam berbagai konteks sebagai perluasan khasanah dan contoh penerapan PBB, untuk mendiseminasikan konsep dan prinsip PBB ke berbagai kalangan, mengkaji kemungkinan penerapannya secara nyata di dunia pendidikan di Indonesia, serta dampaknya dalam meningkatkan apresiasi masyarakat terhadap seni dan budaya. Upaya ini juga perlu dibarengi dengan upaya-upaya pemecahan masalah yang sistematis terhadap permasalahan yang timbul dalam upaya penerapan $\mathrm{PBB}$, misalnya pengetahuan guru dan calon guru tentang seni dan budaya yang tidak terlalu menggembirakan.

\section{DAFTAR PUSTAKA}

Agung, A. A. Gede. 1997. Pengantar Evaluasi Pengajaran. Singaraja: STKIP Singaraja Arsyad, Azhar. 2002. Media Pembelajaran. Jakarta: Raja Grafindo Persada.

Baharudin. dan Wahyuni, Nur Esa. 2008. Teori Belajar \& Pembelajaran. Jogjakarta: Ar-Ruzz Media Group

Brodjonegoro, S.S. (2003) Higher Education Long Term Strategy. Jakarta: Ditjen Dikti.

Budiastra, K. (2000) Model Pengembangan Kreativitas Guru dalam Pembelajaran MIPA. Jakarta, Universitas Terbuka

Budd, M. (1995) Values of Art: Pictures, Poetry and Music. London: Penguin Books

Buska, W., Prihartini, Y., \& Hasnah, N. 2018. Analysis of Students' Arabic Proficiency for Vocabulary Mastery in State Islamic Junior High School in Muaro Jambi. INNOVATIO: Journal for Religious Innovation Studies, 18(1), 51-62.

Buska, W., Prihartini, Y., \& Hasnah, N. 2018. Dirâsah Tahlîliyyah Taqwîmiyyah 'An AlMufradât Fî̀ Kitâb Manân Al-Azîz. Arabiyat: Jurnal Pendidikan Bahasa Arab dan Kebahasaaraban, 5(2), 358-373.

Dewey, J. (1916) Democracy and Education. New York: Macmillan

Danim, S. 2002. Inovasi Pendidikan Dalam Upaya Peningkatan Profesionalisme Tenaga Kependidikan. Bandung, Pustaka Setia.

Dimyati dan Moedjono. 1992. Strategi Belajar Mengajar. Jakarta: Depdikbud.

Eisner, E.W. (1994) Cognition and Curriculum Reconsidered. New York: Teachers College Press.

Fajardo, B.V., Flores, P.D. (a.n.) HUM II: Art and Society. Los Banos: UP-OU.

Hasibuan, Malayu S.P.2001. Organisasi dan motivasi dasar peningkatan produktivitas. Bandung: Bumi Aksara.

Hidayat. 2001. Kecerdasan Emosional. Jakarta: Jelita Akademika.

Harahap, Nasrun dkk. 2002. Teknik Penilaian Hasil Belajar. Jakarta: Bulan Bintang

Imron, Ali. 1996). Belajar dan Pembelajaran. Jakarta: Pustaka Jaya.

Moekijat. 1984. Dasar-dasar motivasi. Bandung: Sumur Bandung.

Masitoh, dkk. 2007. Strategi Pembelajaran TK. Jakarta: Universitas Terbuka.

Mulyasa, E. 2005. Menjadi Guru Profesional. Bandung: Remaja Rosdakarya 
Munandar, Utami. 1999. Pengembangan Kreatifitas Anak Berbakat. Jakarta: Rineka Cipta. Nugraha, Ali., dkk. 2006. Kurikulum dan Bahan belajar TK. Jakarta: Universitas terbuka

Pannen, P. (2002) Contextual Constructivism: Creative Teaching through Indigenous Arts. Asia Fellow Research Report. Bangkok: Asian Scholarship Foundation.

Pidarta, Made. 2007. Landasan Kependidikan. Jakarta: Rineka Cipta.

Prihartini, Y. 2018. Peningkatan Maharah Al Kitabah Melalui Penerapan Media Lauhah Al Juyub Pada Siswa Mtsn Aceh Utara. Jurnal Literasiologi, 1(1), 20-20.

Prihartini, Y., \& Wahyudi, W. 2018. The Development of Integrated Learning Model To Improve Language Skills at Arabic Language. IJER (Indonesian Journal of Educational Research), 3(1), 9-14.

Prihartini, Y., Wahyudi, W., Aliasar, A., Mukhaiyar, M., \& Ungsi, A. O. M. 2018. The Development of Arabic Learning Model by Using Multimedia of Computer at UIN STS Jambi. Al-Ta lim Journal, 25(2), 135-143.

Prihartini, Y., Wahyudi, W., Nuraini, N., \& DS, M. R. 2018. Penerapan Konsep Matematika Dalam Pembelajaran Bahasa Arab Pada FTK Di UIN STS Jambi. Tarbawi: Jurnal Ilmu Pendidikan, 14(2), 15-28.Purwanto, N. 1990. Psikologi Pendidikan, Bandung: Rosdakarya.

Roestyah, N. K. 1991. Strategi Belajar Mengajar. Jakarta: Rineka Cipta.

Romiszowski A.J. 1981. Designing Instructional Systems. New York: Nicolas Publishing Company

Rusyan, Tabarin. 1993. Proses Belajar Mengajar Yang Efektif tingkat Pendidikan Dasar. Bandung: Bina Budhaya.

Suprayogo, I (Eds). 2004. Pendidikan Berparadigma Al-Qur'an, Malang. UIN Malang Press. Sukardjo,M dan Komarudin Ukim. 2009. Landasan Pendidikan. Jakarta: Rajawali Pres

Syah, Muhibbin. 2009. Psikologi Belajar. PT Raja Grafindo Persada : Jakarta

Sagala, Syaiful. 2005. Konsep dan Makna Pembelajaran. Bandung: Alfabeta

Slameto. 1995. Belajar dan Faktor-faktor yang Mempengaruhinya. Jakarta: Rineka Cipta.

Slavin, Robert, E. 1994. Educational Psychology; Theory and Practice. Fourth Edition: Jhon Hopkins University

Soeharto, Karni. 1995. Teknologi Pembelajaran. Surabaya: Intelek Club.

Soetomo. 1993. Dasar-Dasar Interaksi Belajar Mengajar. Surabaya: Usaha Nasional.

Wahyudi, W. 2018. 2 Play And Work In The Curriculum Suatu Tinjauan Filsafat tentang Pengembangan Kurikulum PAUD. SMART KIDS: Jurnal Pendidikan Islam Anak Usia Dini, 1(1), 9-21.

Wahyudi, W. (2018). Tingkat Kelayakan Tes Uas Bahasa Arab Pada Fakultas Ilmu Tarbiyah Dan Keguruan Di Uin Sulthan Thaha Saifuddin Jambi Tahun Ajaran 2016-2017. Jurnal Al-Ashlah, 1(2).

Wahyudi, W., \& Prihartini, Y. (2019, April). Development of Arabic Learning Material Based on Eclectic Method. In 3rd Asian Education Symposium (AES 2018). Atlantis Press.

Werkanis. 2002. Strategi Mengajar dalam Pelaksanaan Proses Belajar Mengajar di Sekolah. Pekanbaru: Dinas Pendidikan Propinsi Riau.

Yusraini, Y., \& Prihartini, Y. 2017. Pembelajaran Bahasa Arab Di Iain Sulthan Thaha Saifuddin Jambi. Penamas, 27(2), 219-230. 